\title{
Eye Disorder
}

National Cancer Institute

\section{Source}

National Cancer Institute. Eye Disorder. NCI Thesaurus. Code C26767.

A non-neoplastic or neoplastic disorder that affects the eye. Representative examples include conjunctivitis, glaucoma, cataract, conjunctival squamous cell carcinoma, uveal melanoma, and retinoblastoma. 